\title{
Investigations of Tertiary volcanic rocks along the south coast of Nûgssuaq and in eastern Disko, 1987
}

\author{
Lotte Melchior Larsen and Asger Ken Pedersen
}

As a continuation of an integrated study of sedimentary and volcanic facies in the Cretaceous to Tertiary West Greenland basin (G. K. Pedersen, 1987; A. K. Pedersen \& Larsen, 1987) early Tertiary volcanic rocks were studied in 1987 along a NW-SE trending composite section, about $120 \mathrm{~km}$ in length, on Nûgssuaq and Disko. The study attempts to establish and describe lithostratigraphic volcanic units in the Tertiary volcanic formations, and through a combination of field mapping, photogrammetry and geochemistry to establish chronostratigraphic horizons through the early Tertiary deposits of the region. In this respect it is essential to identify the same eruptive units as subaerial lava facies and as subaqueous lava or hyaloclastite facies, and to trace subaerial tuffs throughout the area.

In the first part of the season localities along the Vaigat coast of Nûgssuaq from Kugssinerssuaq in the east to Nûssap qáqarssua in the west were investigated. In the second part of the season very poorly known areas in the western and southern part of the Kvandalen region on east Disko were investigated. The field work was supported by the Arctic Station in Godhavn and its cutter Porsild as well as by GGU's cutter J. F. Johnstrup.

\section{South coast of Nagssuaq}

The localities investigated are situated along the western part of the south coast of Nûgssuaq (fig. 1). Information on the volcanic rocks along this part of the

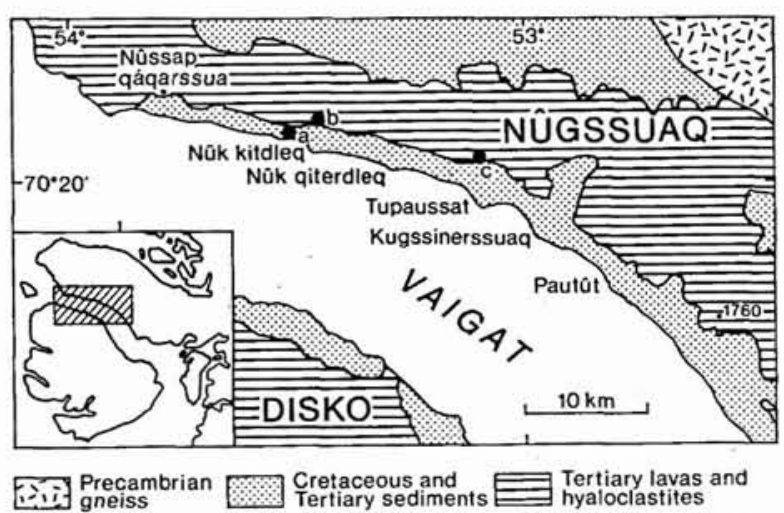

Fig. 1. Investigated area on the south coast of Nûgssuaq. The positions of the three profiles shown in fig. 2 are indicated by a, $\mathrm{b}$ and $\mathrm{c}$. section is given by Steenstrup (1900), Koch (1959), Henderson (1973), Münther (1973), Clarke \& Pedersen (1976) and Henderson et al. (1976), and the section is covered by the geological map sheet 1:100 000 Qutdligssat. In the investigated area the volcanic rocks are very well exposed in up to $1700 \mathrm{~m}$ high mountain sides, but large parts of these are inaccessible due to the steep topography. The basal parts of the hyaloclastite deposits overlying sediments are, however, usually accessible. The volcanic rocks of the section belong to the Vaigat Formation except for some high mountain tops. A detailed lithostratigraphy for the Vaigat Formation has been established for the nearby parts of northern Disko (Pedersen, 1985), and attempts were made in 1987 to extend this stratigraphy to Nûgssuaq.

The Vaigat Formation on Disko is divided into six members which were formed by two major igneous events. The first event gave rise to the voluminous picritic volcanics of the Naujánguit Member and two minor sediment contaminated volcanic systems therein, the Asuk and Kûgánguaq Members, while the Qordlortorssuaq Member basalts constitute the waning phase of the event. Local erosion and the formation of a widespread water-filled basin (subsidence) took place between the two igneous events. The second event gave rise to the voluminous picritic volcanics of the Ordlingassoq Member within which are enclosed the alkaline lavas of the Manîtdlat Member.

During the field work on Nûgssuaq special attention was paid to locating the boundary between the rocks from the two major igneous events recognized on Disko, i.e. the base of the Ordlingassoq Member.

The following describes the lower hyaloclastite deposits and subaerial lava flows from the first igneous event, followed by the upper hyaloclastite deposits and subaerial lava flows from the second igneous event.

Lower hyaloclastite deposits. Thick hyaloclastite deposits laid down in a water-filled basin form the basal part of the volcanic sequence from Nûssap qáqarssua to Tupaussat. The deposits in the basin consist in upward sequence of mudstone, hyaloclastite tuffs and foresetbedded hyaloclastites, the latter being the dominant lithology. The hyaloclastite sequence just west of Nûk kitdleq (fig. 2a) is the thickest of its kind (c. $650 \mathrm{~m}$ ) on Disko and Nûgssuaq and exemplifies the development in the basin. 

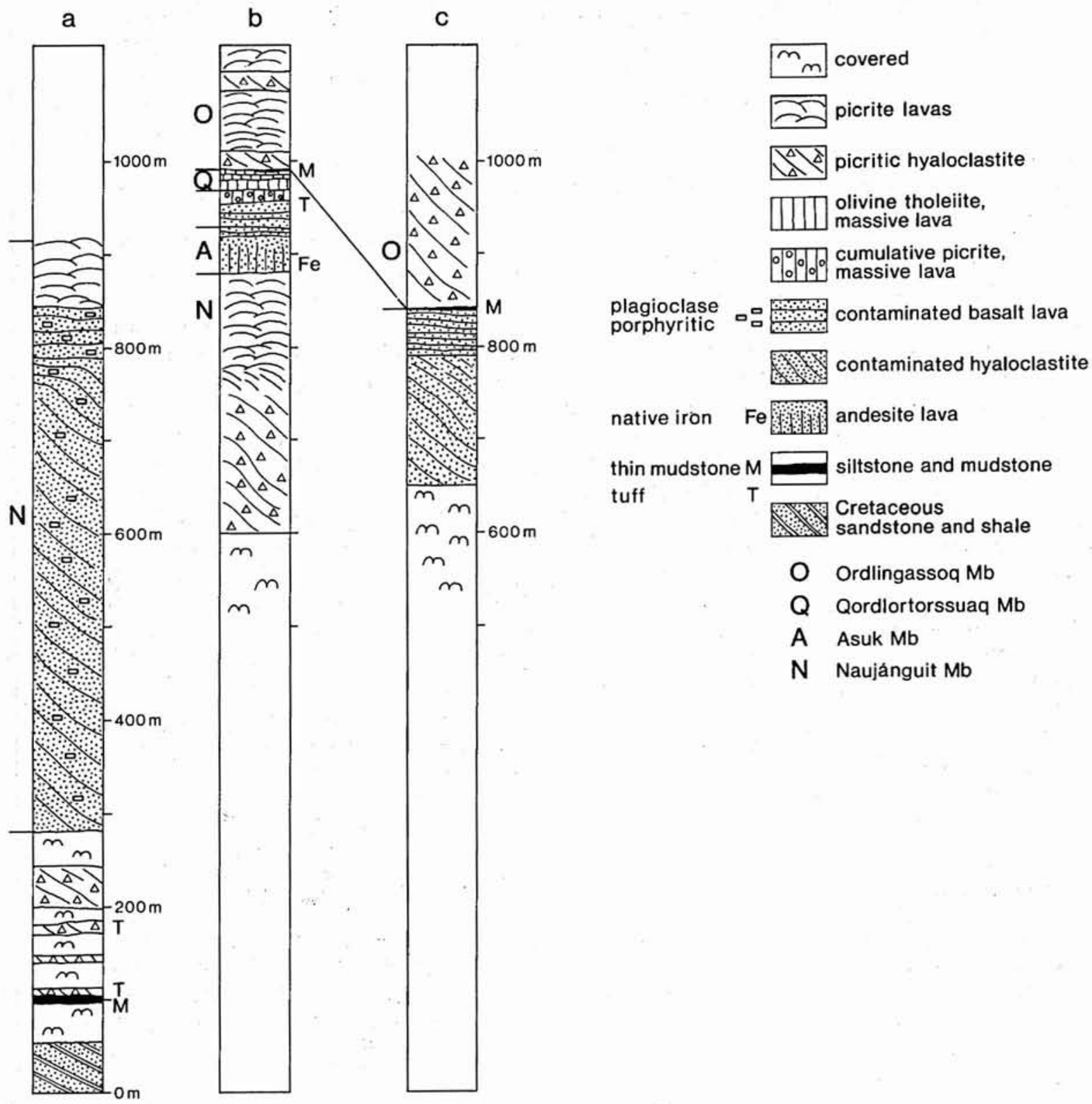

Fig. 2. Profiles through the Vaigat Formation on the south coast of Nûgssuaq. The location of the profiles is shown in fig. 1.

The lower part of the sequence is $c .140 \mathrm{~m}$ thick and is seen in slightly dislocated or isolated exposures. At the bottom c. $5 \mathrm{~m}$ mudstone is exposed which is finely intercalated with hyaloclastite in the upper metre. This is covered by a sequence of sandy to silty hyaloclastite tuff units with fining-upwards structure, intercalated with coarser units with pillow fragments. The hyaloclastites originated from picritic magma of a type characteristic of the Naujánguit Member on Disko.

The upper part of the sequence is exposed in near- vertical cliffs. It is about $500 \mathrm{~m}$ thick and is composed of regularly foreset-bedded coarse hyaloclastites with pillow fragments of olivine + plagioclase porphyritic contaminated basalt. These hyaloclastites originated from a sequence of yellowish-brown subaerial lava flows which forms a marker horizon within the predominantly grey picritic lava flows towards the west.

The hyaloclastite tuffs in the lower part of the sequence are interpreted as deposited from suspension flows possibly from volcanic sources many kilometres 
away. In contrast, the foreset-bedded hyaloclastites were formed locally, where subaerial lava flows entered the sea. The deposits gradually filled in the basin, prograding from the west and north-west.

Contaminated volcanic rocks with native iron. In the steep mountain side north of Nûk kitdleq a sequence of sediment-contaminated volcanic rocks is exposed (fig. 2b). A striking feature is an up to $45 \mathrm{~m}$ thick rusty brown weathering lava flow with native iron which rests on a sequence of picritic lavas. The brown lava is an erosion resistant columnar jointed andesite with disseminated graphite and native iron. It was first observed on the coast and identified through the study of scree blocks by Steenstrup (1883). The lava is exposed over a distance of $1.2 \mathrm{~km}$ and thins rapidly, and stops towards the east. Heaps of strongly graphitic scoria occur at the base of the flow and are rich in xenoliths of magmamodified shale and of a non-graphitic vesicular basalt. A sequence of grey-brown lava flows of contaminated basalts cover the andesite lava or are dammed up against.it. Due to lithological similarities these volcanic rocks are tentatively correlated with the Asuk Member on Disko.

\section{Table 1. Chemical compositions of contaminated and uncontaminated volcanic rocks from the Vaigat and Maligât Formations}

\begin{tabular}{lrrrr}
\hline & \multicolumn{1}{c}{1} & \multicolumn{1}{c}{2} & \multicolumn{1}{c}{3} & \multicolumn{1}{c}{4} \\
\hline $\mathrm{SiO}_{2}$ & 50.02 & 45.13 & 48.73 & 49.18 \\
$\mathrm{TiO}_{2}$ & 0.98 & 1.28 & 2.51 & 1.42 \\
$\mathrm{Al}_{2} \mathrm{O}_{3}$ & 12.59 & 11.49 & 14.13 & 14.56 \\
$\mathrm{Fe}_{2} \mathrm{O}_{3}$ & 1.12 & 2.56 & 4.23 & 2.55 \\
$\mathrm{FeO}$ & 8.66 & 9.02 & 8.18 & 8.00 \\
$\mathrm{MnO}$ & 0.17 & 0.19 & 0.20 & 0.17 \\
$\mathrm{MgO}$ & 14.94 & 17.84 & 7.15 & 9.66 \\
$\mathrm{CaO}$ & 8.03 & 10.54 & 11.19 & 10.42 \\
$\mathrm{Na}{ }_{2} \mathrm{O}$ & 1.38 & 1.25 & 2.29 & 1.65 \\
$\mathrm{~K}_{2} \mathrm{O}$ & 0.29 & 0.06 & 0.31 & 0.24 \\
$\mathrm{P}_{2} \mathrm{O}_{5}$ & 0.13 & 0.13 & 0.24 & 0.15 \\
volat. & 1.73 & 0.61 & 0.60 & 1.63 \\
& 100.04 & 100.10 & 99.76 & 99.63 \\
\hline
\end{tabular}

1. GGU 340711, Vaigat Formation: Contaminated Mg-rich basalt, pillow fragment from the pillow breccia formed late in the first volcanic event. Tupaussat, south Nugssuaq.

2. GGU 340755, Vaigat Formation: Picrite, pillow fragment in pillow breccia from the Ordlingassoq Member (second volcanic event). Tupaussat, south Nagssuaq.

3. GGU 340844, Maligât Formation: Olivine + plagioclase porphyritic basalt, pillow fragment in pillow breccia from the Rinks Dal Member. Westernmost Kvandalen, Disko.

4. GGU 318829, Maligât Formation: Contaminated Mg-rich basalt lava from the Niaqussat Member. Peak 1240 north of Kvandalen, Disko.
Olivine porphyritic basalt lavas. A marker horizon above the inferred Asuk Member at Nûk kitdleq is formed by $30-40 \mathrm{~m}$ of prominent erosion-resistant grey to dark grey lava flows (fig. 2b). Towards the west this horizon is situated in a subaerial lava sequence, while towards the east the horizon underlies the eastward thickening upper hyaloclastite deposits, until the lavas in the horizon either disappear or develop into hyaloclastite facies 6 to $8 \mathrm{~km}$ further east. The lavas consist of olivine-poor tholeiitic basalt and olivine cumulative tho: leiitic basalt. These lava flows formed in a period of volcanic stagnation, and the horizon is correlated with the Qordlortorssuaq Member which completed the first volcanic event on Disko.

Contaminated olivine porphyritic basalts at Tupaussat. A sequence of light yellow-brownish weathering pahoehoe lavas of contaminated basalts forms subaerial lavas just below the prominent upper hyaloclastite deposits, stretching from just west of Nûk qiterdleq to Tupaussat. The sequence is coeval with or slightly older than the lava flows assigned to the Qordlortorssuaq Member further west. In the corrie north-east of Tupaussat (fig. $2 \mathrm{c}$ ) the sequence consists of more than $100 \mathrm{~m}$ of hyaloclastite rich in decimetre-sized pillows, covered by $40 \mathrm{~m}$ of pahoehoe lavas, while a few kilometres further to the east the whole sequence is in hyaloclastite facies. The rocks are olivine porphyritic contaminated basalts (Table 1, no 1), derived from picrite magma.

The second igneous event. Above the lava sequence assigned to the Qordlortorssuaq Member, the volcanic sequence from the Vaigat Formation seems to consist of picrites and olivine-poor tholeiitic basalts, developed either in subaerial or subaqueous facies. The chemical composition of pillows (Table 1, no 2) and their lithology can be correlated with the Ordlingassoq Member on Disko. The subaqueous facies is described below.

An upper sequence of hyaloclastites extends for about $36 \mathrm{~km}$ along the Vaigat coast from just north of Nûk kitdleq in the west to point 1760 east of Pautût in the east. At Nûk kidtleq two thin hyaloclastite horizons, separated by 25 to 30 picrite flows, start in the otherwise subaerial lava plateau, and increase gradually in thickness towards the east until they merge. Thereafter they continue eastwards as a steadily thickening single horizon. Decimetre to metre thick deposits of mudstone with plant fossils occur at the base of the lower of these hyaloclastite horizons, and these mudstones, while still unconsolidated, were often deformed by advancing hyaloclastite beds. At Kugssinerssuaq the hyaloclastites overlie about $50 \mathrm{~m}$ of black shale assigned to the Naujât Member by Koch (1959). The hyaloclastites contain 
pillow fragments of picrite and olivine tholeiite, and they are regularly foreset bedded. The infilling pattern of the basin is quite complex in detail, but in general the hyaloclastite deposits have formed from subaerial lavas flowing into the water from the west and north-west. At the base of some breccia beds are found rounded beach pebbles of picrite and sometimes of metre-sized fragments of subaerial lava flows brought into the basin by advancing lava fronts.

On Disko, alkaline picrites and alkaline basalts form a separate unit (Manîtdlat Member) within the Ordlingassoq Member. Careful sampling of pillow fragments in the hyaloclastite from Tupaussat to Kugssinerssuaq has not revealed the presence of alkaline basic rocks in the area. If present at all, the Manitdlat Member is restricted to the area between Nûk qiterdleq and Tupaussat.

\section{Eastern Disko}

The field work in eastern Disko was centred in the region around Kvandalen where the pre-existing information on the volcanic rocks is very sparse. Cretaceous and early Tertiary sediments occupy the lower levels up to 450 to $700 \mathrm{~m}$ a.s.l., and the interfingering and overlying volcanics belong to the Maligât Formation. Four areas in this region were investigated (fig. 3).

Marine shale. In the westernmost part of Kvandalen a recently retreated glacier has left an exposure below the base of the volcanic succession of about $20 \mathrm{~m}$ of dark grey silty micaceous shale. The shale contains plant debris including leaf imprints of needle and broadleafed species. It also contains well-preserved mussels up to $1 \mathrm{~cm}$ in size which N. Noe-Nygaard (personal communication) has identified as Nucula sp. Nucula is a marine genus, and this indicates that the water basin was connected to the sea at least temporarily.

Hyaloclastites. A hitherto unknown sequence of hyaloclastites was discovered in the Kvandalen region (fig. 3). It consists of two units.

The lower unit is best developed in the westernmost part of Kvandalen where it is around $20 \mathrm{~m}$ thick. It consists of several metre-thick layers of relatively fineclastic matrix-rich hyaloclastite with sparse pillows, rarely exceeding $5 \mathrm{~cm}$ in size, of plagioclase-porphyritic basalt. Trains of basalt pebbles and rounded shale xenoliths are seen at some levels. Centimetre-thick lenses and irregular layers of mudstone occur at two levels, one forming the top of the unit.

The upper unit is up to $90 \mathrm{~m}$ thick and consists of a regularly foreset-bedded coarse hyaloclastite locally

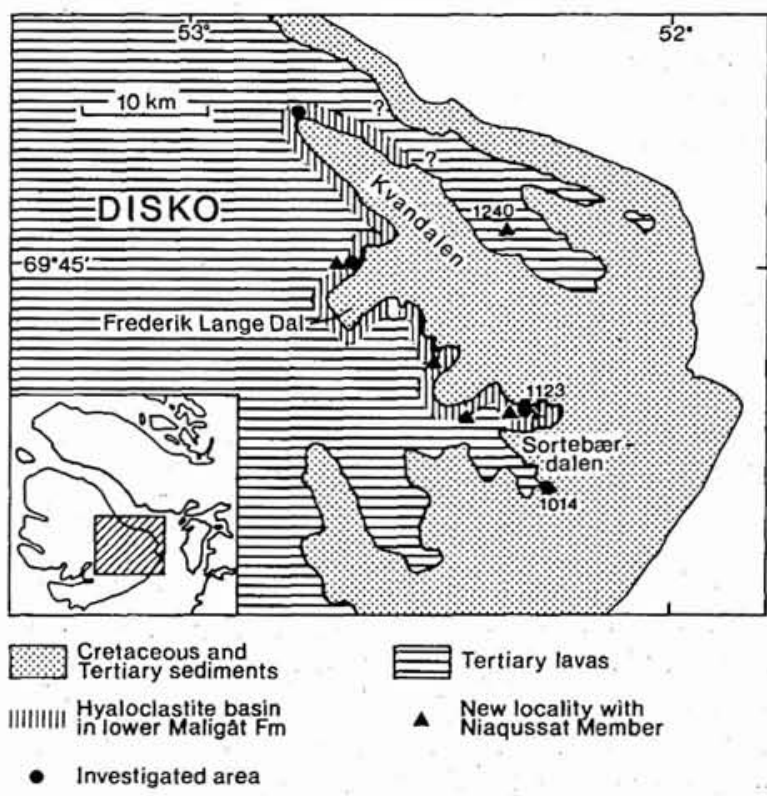

Fig. 3. Investigated area in eastern Disko.

rich in decimetre-sized pillows, covered by subaerial pahoehoe lavas belonging to the same eruptive unit as the hyaloclastite. The rock is a tholeiitic basalt (Table 1, no 3) with abundant microphenocrysts of platy olivine and phenocrysts of plagioclase. In Frederik Lange Dal two unusual composite lavas with basal parts of picrite and upper parts of olivine-poor basalt belong to the unit.

This hyaloclastite sequence forms an important marker horizon that has been observed over a large part of the Kvandalen region (fig. 3 ). It belongs to the lowest part of the Maligât Formation and demonstrates the existence of an easterly, water-filled sedimentary basin with a water depth of around $50 \mathrm{~m}$. A considerable volume of this basin was completely filled in with hyaloclastite.

Subaerial lavas. After the infilling of the basin subaerial plateau basalt lavas became widespread. In the eastern part of Kvandalen and in Sortebærdalen quartzo-feldspathic sandstones occur between the lower lava flows, and a few coal layers up to several metres thick are present in some of these sandstones. Towards the west the sandstones diminish in thickness, and they are entirely absent in the westernmost part of Kvandalen. The major part of the subaerial lavas, as well as the underlying hyaloclastites, belong to the Rinks Dal Member of the Maligât Formation.

Nordfjord Member. Pedersen \& Larsen (1987) reported 


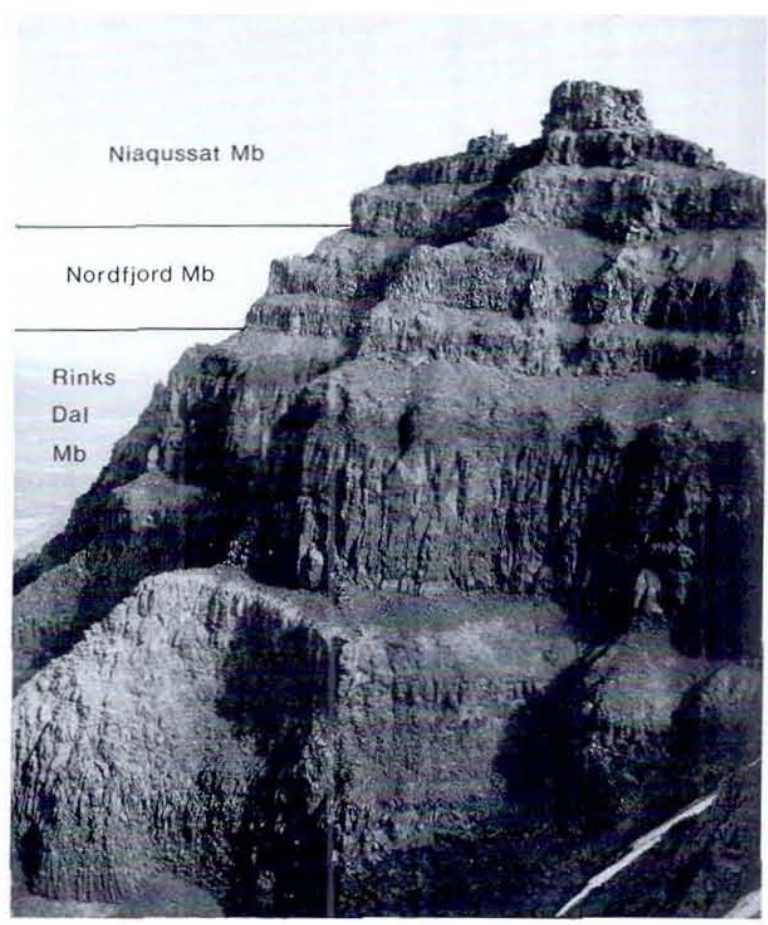

Fig. 4. Peak $1123 \mathrm{~m}$ in eastern Disko, seen from the west. Subaerial lavas of the Mâligat Formation, with division into members as shown.

on the widespread occurrence of volcanic rocks from the Nordfjord Member, overlying the Rinks Dal Member, in the eastern parts of Nûgssuaq and Disko. This summer lava flows of silica-enriched basalt from this member were found to the south of Kvandalen, and it was established that a native iron-bearing lava from this member, known from the ridge to the north of Kvandalen, does not extend south of Kvandalen.

Niaqussat Member. Volcanic rocks from the Niaqussat Member overlie the Nordfjord Member and constitute the youngest volcanic rocks known from Disko (Pedersen, 1975). In western Disko widespread lava sequences belong to the Niaqussat Member; they include several iron-bearing lavas as well as iron-bearing craters and intrusions.

A characteristic feature of this member is the occurrence of silica-enriched olivine microporphyritic pahoehoe lavas (Table 1, no 4) which show flow-folding patterns and inhomogeneous vesicle distribution. Such lavas were identified among the uppermost lavas in Frederik Lange Dal, and they form the uppermost lava flows on the highest peaks along the south wall of Kvandalen (figs 3 and 4).
This discovery considerably extends the known range of the Niaqussat Member towards the east. It demonstrates that the volcanic sequence in eastern Disko, though thinned and degenerated relative to that in western Disko, still comprises the whole Maligât Formation. This is very valuable for the time-integrated basin analysis of the region.

Acknowledgement. The field work was supported by the Arctic Station in Godhavn.

\section{References}

Clarke, D. B. \& Pedersen, A. K. 1976: Tertiary volcanic province of West Greenland. In Escher, A. \& Watt, W. S. (edit.) Geology of Greenland, 364-385. Copenhagen: Geol. Surv. Greenland.

Henderson, G. 1973: The geological setting of the West Greenland basin in the Baffin Bay region. Pap. geol. Surv. Can. 71-23, 521-544.

Henderson, G., Rosenkrantz, A. \& Schiener, E. J. 1976: Cretaceous-Tertiary sedimentary rocks of West Greenland. In Escher, A. \& Watt, W. S. (edit.) Geology of Greenland, 340-362. Copenhagen: Geol. Surv. Greenland.

Koch, B. E. 1959: Contribution to the stratigraphy of the non-marine Tertiary deposits on the south coast of the Nûgssuaq peninsula, northwest Greenland, with remarks on the fossil flora. Bull. Gronlands geol. Unders. 22 (also Meddr Gronland 162,1), $100 \mathrm{pp}$.

Münther, V. 1973: Results from a geological reconnaissance around Svartenhuk Halvø, West Greenland. Rapp. Grønlands geol. Unders. 50, $26 \mathrm{pp}$.

Pedersen, A. K. 1975: New mapping in north-western Disko 1972. Rapp. Gronlands geol. Unders. 69, 25-32.

Pedersen, A. K. 1985: Lithostratigraphy of the Tertiary Vaigat Formation on Disko, central West Greenland. Rapp. Grønlands geol. Unders. 124, $30 \mathrm{pp}$.

Pedersen, A. K. \& Larsen, L. M. 1987: Early Tertiary volcanic rocks from eastern Disko and south-eastern Nûgssuaq. Rapp. Gronlands geol. Unders. 135, 11-17.

Pedersen, G. K. 1987: New sedimentological data on Lower Tertiary shales from Disko and Nûgssuaq, West Greenland. Rapp. Gronlands geol. Unders. 135, 17-25.

Steenstrup, K. J. V. 1883: Om Forekomsten af Nikkeljern med Widmannstättenske Figurer i Basalten i Nordgrønland. Meddr Gronland 4, 113-132.

Steenstrup, K. J. V. 1900: Beretning om en Undersøgelsesrejse til Øen Disko i Sommeren 1898. Meddr Gronland 24, 249-306.
A. K. P., Geologisk Museum, Oster Voldgade 5-7, DK-1350 Copenhagen $K$. Denmark. 